\title{
The Role of Sodium in Intestinal
}

\section{Glucose Absorption in Man}

\author{
Ward A. Olsen and Franz J. Ingelfinger \\ From the Evans Memorial Department of Clinical Research, University Hospital, and the \\ Department of Medicine, Boston University School of Medicine, Boston University \\ Medical Center, and the 5th and 6th Medical Services (Boston University), \\ Boston City Hospital, Boston, Massachusetts 02118
}

A B S TRACT The effect of luminal sodium on intestinal glucose absorption at a variety of glucose concentrations was studied with a segmental perfusion technique in normal subjects.

Uphill glucose transport was inhibited with sodium-free perfusions with either mannitol or Tris- $\mathrm{HCl}$ as the osmotic replacement of sodium $(P<0.01-P<0.001)$. This effect did not appear to be the result of solvent drag, as increasing net water absorption without supplying sodium to the lumen did not increase glucose absorption.

Downhill glucose transport (infusion concentrations of 6.0-27.8 mmoles/liter), on the other hand, was not affected by the absence of sodium in the infusion solution.

Glucose concentrations of upper intestinal fluid after normal carbohydrate meals were usually found to exceed serum concentrations ; thus, downhill glucose absorption, with, at most, a very limited dependence upon intraluminal sodium concentration, may account for a significant part of normal carbohydrate absorption.

\section{INTRODUCTION}

Intestinal absorption of glucose is related in some manner to absorption of sodium ion. Studies both in vitro $(1,2)$ and in vivo (3-6) have shown increased sodium transport during absorption of actively absorbed monosaccharides, even when the sugar studied was not metabolizable. In addition, active absorption of sugars appears to have an absolute dependence on the presence of sodium on

\footnotetext{
Received for publication 6 October 1967 and in revised form 11 December 1967.
}

the mucosal side of the intestinal membrane when studied in vitro $(7-10)$. This observation is supported by studies in vivo which have shown a reduction in active sugar transport when sodium was not added to the luminal fluid $(11,12)$. Absorption of a number of other actively transported substances such as amino acids $(13,14)$, bile salts (15), and uracil (13), also depends on the presence of sodium. These observations have led to the formulation of two different concepts of the role of sodium in active transport of nonelectrolytes, one concept which suggests that the main effect of sodium is to participate in carrierfacilitated entrance into the cell $(16,2)$, and the other which postulates that the effect of sodium is within the cell and important in the production of the energy required for uphill transport (17). According to the latter concept, if luminal substrate concentration is high enough, absorption will occur in a downhill direction by carriermediated diffusion regardless of the sodium concentration in the intestinal lumen.

The present studies were designed to examine the role of intraluminal sodium in glucose absorption in man.

\section{METHODS}

24 healthy young people were studied on 53 occasions. Paired segmental intestinal perfusion studies were done in random order. Glucose was infused with either sodium at physiological concentration or with a complete osmotic replacement of sodium, one infusion following the other at the same sitting. Thus each subject served as his own control, and absorption rates of glucose with and without infused sodium were compared.

The small intestine was intubated with a two-lumen 
polyvinyl tube weighted with a mercury bag (18); the collecting port was $10 \mathrm{~cm}$ from the infusion orifice. After an overnight fast (except for water), the position of the tube was determined fluoroscopically and the intestinal segment perfused with test solution delivered by a peristaltic pump ${ }^{1}$ at a rate of $15 \mathrm{ml} / \mathrm{min}$. Usually the tube was allowed to pass further into the small intestine after a second overnight period, and the studies were repeated the following day. All solutions contained the nonabsorbable marker polyethylene glycol 4000, PEG, (1922) at a concentration of $0.5 \%$ and glucose ${ }^{2}$ at one of the following concentrations: $1.0,1.7,3.4,6.0,11.1,20.0$, and $27.8 \mathrm{mmoles} / \mathrm{liter}$. The sodium-free solutions contained mannitol ${ }^{3}$ as the osmotic replacement of sodium; the other solutions contained sodium at a concentration of $140 \mathrm{meq} /$ liter as sodium chloride, except those solutions where the glucose concentration was 27.8 mmoles/liter, in which case the sodium concentration was reduced to $132 \mathrm{meq} /$ liter to preserve isotonicity. The solutions were adjusted to isotonicity ( $290 \pm 10 \mathrm{mOsm} /$ liter) with mannitol where necessary.

After a $30 \mathrm{~min}$ equilibration period, fluid from the aspirating site was obtained by siphonage and collected over ice in two or more successive 10-20-min collections. The PEG and glucose concentrations in successive collections varied little, $2.3 \pm 0.2 \%$ (mean $\pm \mathrm{SE}$ ) and 9.9 $\pm 0.8 \%$, respectively. Duplicate protein-free filtrates (23) were made of an aliquot of infusion solution and of each of the collected specimens. The filtrates were kept iced and frozen within $6 \mathrm{hr}$ of collection for subsequent determination of PEG and glucose concentrations. Both glucose and PEG were stable in the frozen filtrates for at least 8 months. Additional aliquots were frozen for determination of sodium and osmolality. Glucose could never be detected in collections during perfusions with glucose-free solutions, even during a $10 \%$ intravenous infusion of glucose that produced a serum glucose of $150-300 \mathrm{mg} / 100 \mathrm{ml}$. On three occasions a perfusion with $6 \mathrm{~mm}$ glucose was followed immediately with a perfusion of glucose-free solution; glucose disappeared from the sampled fluid within $10 \mathrm{~min}$ which indicated that the 30 min equilibration period was long enough to prevent contamination of the test segment with glucose from the preceding infusion. During many of the studies, venous blood was drawn at the beginning of the study and at the end of the infusion period; serum was separated and protein-free filtrates were prepared for glucose analysis.

24 paired studies were done on five subjects with infusions of 3.4 and $11.1 \mathrm{~mm}$ glucose using Tris (hydroxymethy1)aminomethane 4 titrated to a $\mathrm{pH}$ of 7.4

\footnotetext{
1 Model 600-1200, Harvard Apparatus Co., Dover, Mass.

${ }^{2}$ D-glucose, Fisher certified, ACS, Fisher Scientific Co., Fair Lawn, N. J.

${ }^{3}$ D-mannitol, Fisher certified reagent, Fisher Scientific Co., Fair Lawn, N. J.

4 Fisher certified reagent, Fisher Scientific Company, Fair Lawn, N. J.
}

TABLE I

Effect of Infusion Studies on Serum Glucose Concentration

\begin{tabular}{ccc}
\hline $\begin{array}{c}\text { Infusion glucose } \\
\text { concentration }\end{array}$ & $\begin{array}{c}\text { No. of } \\
\text { studies }\end{array}$ & Serum glucose* \\
\hline $\begin{array}{c}\text { mmoles/liter } \\
\text { No infusion }\end{array}$ & 17 & mmoles/liter \\
1.7 & 2 & $4.7 \pm 0.2$ \\
3.4 & 16 & $4.4 \pm 0.3$ \\
11.1 & 14 & $4.4 \pm 0.1$ \\
27.8 & 2 & $5.5 \pm 0.2$ \\
\hline
\end{tabular}

* Blood was drawn at the end of perfusion at each of the infusion concentrations. The values are expressed as mean $\pm \mathrm{SE}$.

with hydrochloric acid as the osmotic replacement of sodium.

Chemical determinations. PEG was measured by a modification of Hyden's method (24). $3 \mathrm{ml}$ of water and $4 \mathrm{ml}$ of $30 \%$ trichloroacetic acid with $5 \% \mathrm{BaCl}_{2}$ were added to $1 \mathrm{ml}$ of protein-free filtrate. The mixture was mixed by inverting the test tube five times and allowing it to stand at room temperature for $55 \mathrm{~min}$. The turbidity was read spectrophotometrically at $650 \mathrm{~m} \mu$. Glucose was measured by a glucose oxidase method (25), a modification of the method of Huggett and Nixon (26). Sodium was measured by flame photometry, ${ }^{5}$ and osmolality by freezing point depression. ${ }^{6}$

Calculations. Glucose absorption in $\mu$ moles per hour over test segment was calculated by the formula : absorption $=1000 \mathrm{I}\left(\mathrm{G}_{1}-\mathrm{P}_{1} \mathrm{G}_{\mathrm{c}} / \mathrm{P}_{\mathrm{c}}\right)$, where $\mathrm{I}=$ infusion rate in liters per hour; $G_{1}=$ infusion glucose concentration in mmoles/liter; $\mathrm{G}_{\mathrm{c}}=$ collection glucose concentration in mmoles/liter; $\mathrm{P}_{1}=$ infusion $\mathrm{PEG}$ concentration; and $\mathrm{P}_{\mathrm{c}}$ $=$ PEG concentration in the collected sample.

\section{RESULTS}

Effect of intestinal perfusion on serum glucose concentration. Serum glucose did not change appreciably during any of the 51 studies in which it was measured. Table I shows the mean values in a fasting state and after perfusion at various glucose concentrations. Thus any glucose movement from lumen to blood at infusion concentrations of 1.0, 1.7, and 3.4 mmoles/liter occurred against a concentration gradient, and absorption from concentrations of $6.0,11.1,20.0$, and 27.8 mmoles/ liter occurred down a concentration gradient.

Sodium concentrations within the intestinal lumen. During infusions of glucose with isotonic

${ }^{5}$ Clinical Flame Photometer, model KY, Baird-Atomic, Inc., Cambridge, Mass.

'Advanced Osmometer, Advanced Instruments, Inc., Newton Highlands, Mass. 


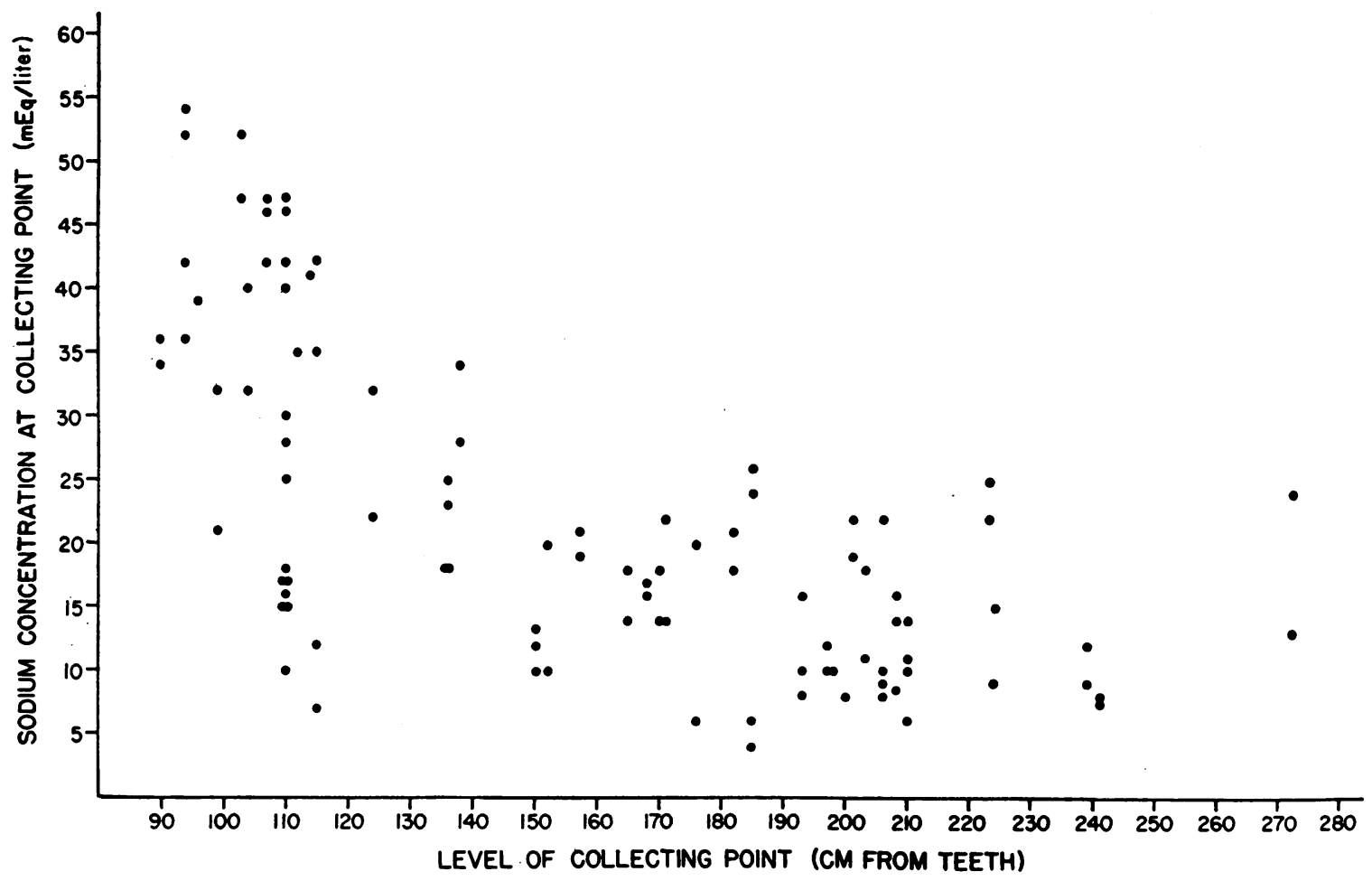

FIGURE 1 Sodium concentration at the collection point during perfusions of sodium-free fluid. Each plot represents the mean of determinations of two or more successive samples after equilibration.

sodium chloride, the sodium concentration of the collected fluid averaged $140 \mathrm{meq} / \mathrm{liter}$ regardless of the glucose concentration of the infusion, and PEG concentrations were somewhat higher than the concentration of the infusing solution, which indicated net water absorption along the segment.

Fig. 1 demonstrates the sodium concentrations of the collection fluid during infusion of sodium-free fluid. It can be seen that a marked lowering of sodium concentration occurred. In fact it is likely that much of the test segment was exposed to a sodium concentration substantially less than that of the fluid reaching the collecting orifices. Dilution of PEG occurred during infusions of sodium-free fluid, suggesting addition of water to the segment; the dilution decreased as more distal intestine was studied.

Relation of glucose absorption to presence of infused sodium. Fig. 2 shows the effect of replacing sodium with mannitol on uphill glucose transport. In only 3 of the 41 studies was glucose absorption greater from a sodium-free perfusion than from its control. A significant inhibition of absorption occurred in the absence of sodium at all three concentrations (mmoles/liter) (23\% at $1.0, P<0.01 ; 21 \%$ at $1.7, P<0.01 ; 24 \%$ at 3.4 , $P<0.001$; paired analysis). Glucose concentration in the aspirations obtained during mannitol perfusions was higher than in the samples collected during sodium perfusions despite the greater dilution of PEG.

Fig. 3 shows the relation of downhill glucose absorption to sodium in the infusion. Though a small inhibition by the mannitol perfusions did occur $(7,6,2.3$, and $2.0 \%$ for infusion concentrations of $6.0,11.1,20.0$, and 27.8 mmoles/liter, respectively), it was not significant statistically (paired analysis).

Replacement of sodium with Tris- $\mathrm{HCl}$. Fig. 4 demonstrates that the effect of sodium replacement is not specific for mannitol. Replacement with an osmotic equivalent of Tris- $\mathrm{HCl}$ resulted in a significant reduction in glucose absorption at a glucose concentration of 3.4 mmoles/liter $(P<0.005$, paired analysis), but not at a concentration of 11.1 mmoles/liter. 

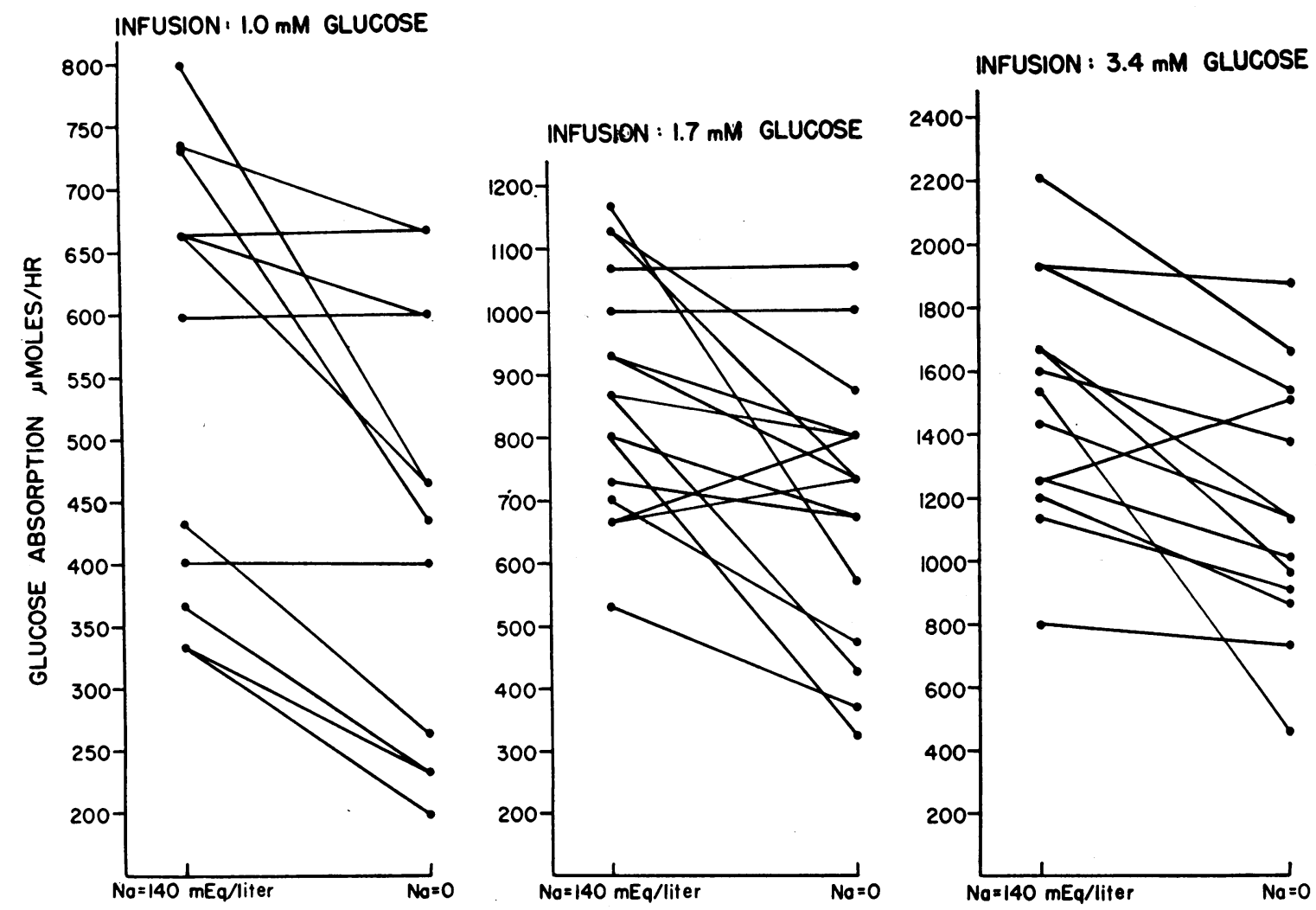

FIGURE 2 "Uphill" glucose absorption related to presence or absence of sodium in the infusion solution. Points connected by a line represent a paired study. Significant inhibition of absorption occurred when sodium was absent at each of the concentrations $(P<0.01$ for glucose concentrations of 1.0 and 1.7 mmoles/liter and $<0.001$ for concentration of 3.4 mmoles/liter).

The effect of water absorption on glucose absorption. To evaluate the possibility that increased uphill absorption of glucose in the presence of sodium depended on enhanced water absorption and consequent solvent drag, paired studies were done at a glucose concentration of 1.7 mmoles/ liter, and absorption from an isotonic mannitol solution was compared with absorption from a hypotonic solution ( $150 \mathrm{mOsm} /$ liter $)$. No sodium was present in either infusion solution. Table II shows that hypotonic infusions did not enhance glucose transport. In fact, they appeared to inhibit it. That water absorption was indeed increased by the hypotonic infusion is suggested by $P E G$ concentration changes, which indicated that mean water secretion of $109 \mathrm{ml} / \mathrm{hr}$ occurred during isotonic infusion, and absorption of $57 \mathrm{ml} / \mathrm{hr}$ occurred during hypotonic infusion. Although others have used a two-lumen technique such as this to estimate water movement $(4,27)$, contamination of the test segment with unknown amounts of fluid from above has prevented its acceptance as a reliable technique for studying water absorption (28). However, as the maximum amount of contamination is relatively small $(29,30)$, the conclusion that our hypotonic infusions resulted in a marked change in water movement seems valid.

Meal Studies. Although intestinal glucose concentrations after normal meals have never been directly measured, it has been thought that most glucose absorption in man occurs against a concentration gradient (31). However, an appreciable amount of starch is hydrolyzed to glucose by amylase (32), and it is thought that at least a significant fraction of the glucose produced by sucrose hydrolysis escapes from the site of hydrolysis on the mucosal surface and returns to the intestinal lumen (25). It was therefore of interest 

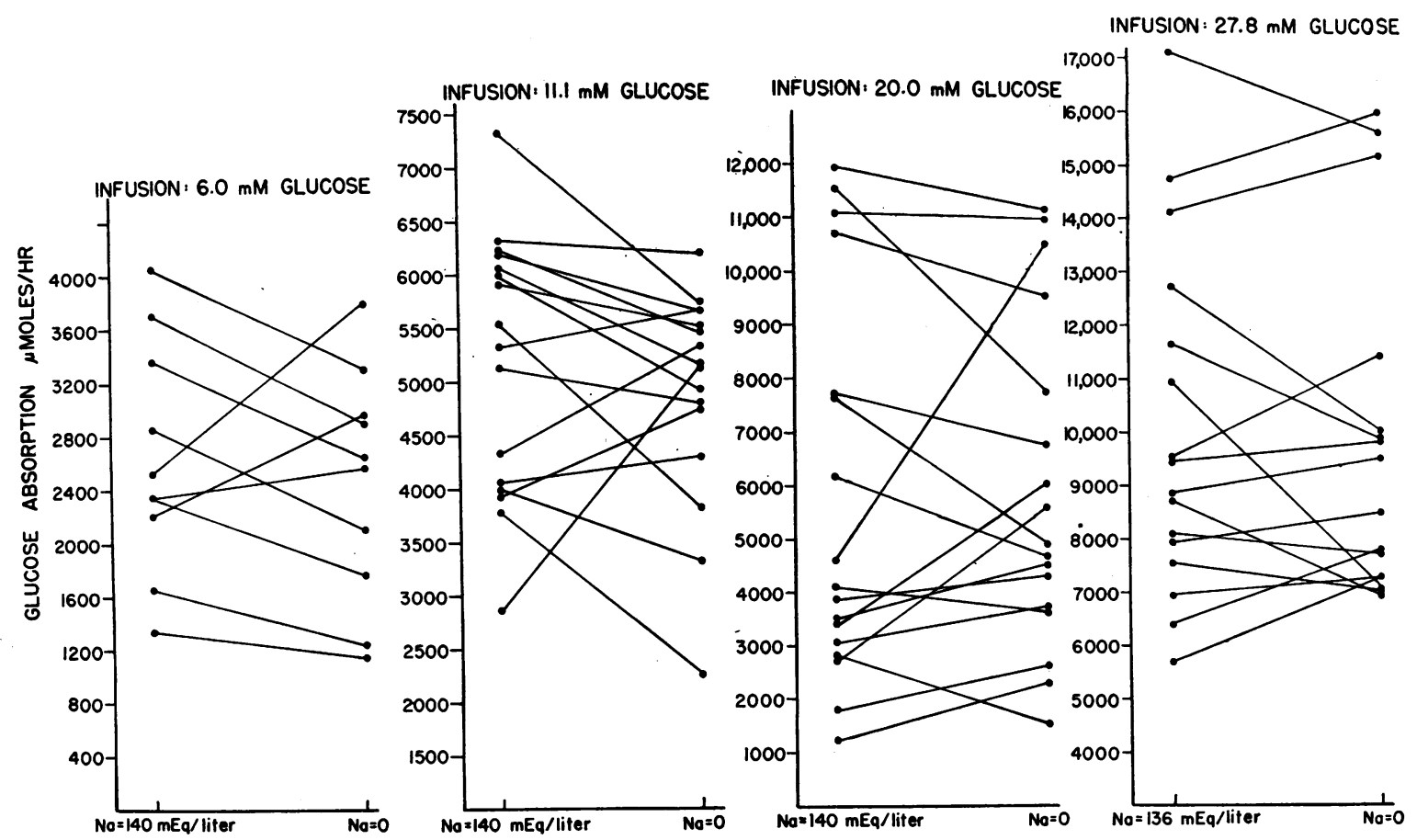

FIGURE 3 "Downhill" glucose absorption related to presence or absence of sodium in infusion solution. Paired studies are represented by connecting points. No significant inhibition of absorption occurred with the absence of sodium.

to determine whether luminal concentrations of glucose in man ever reached levels such that downhill transport could occur. We therefore fed normal subjects one of three meals, the composition of which is estimated in Table III, and collected, over ice, serial 10-min aspirations from the small intestine through a single $2 \mathrm{~mm}$ polyvinyl tube. The three meals were ordinary meals purchased from a restaurant; the first three subjects were asked to select a menu that pleased them, providing that

TABLE II

Effect of Hypotonic Infusion on Glucose Absorption*

\begin{tabular}{|c|c|c|}
\hline Level & $\begin{array}{l}\text { Infusion: } 1.7 \mathrm{~mm} \text { glucose, } \\
\text { isotonic with mannitol } \\
\text { glucose absorption }\end{array}$ & $\begin{array}{l}\text { Infusion: } 1.7 \mathrm{~mm} \text { glucose, } \\
\text { half isotonic with mannitol } \\
\text { glucose absorption }\end{array}$ \\
\hline $\mathrm{cm}$ & 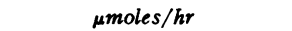 & 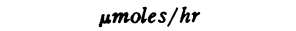 \\
\hline 77 & 1232 & 1032 \\
\hline 90 & 1432 & 799 \\
\hline 93 & 1199 & 999 \\
\hline 113 & 1065 & 1065 \\
\hline 181 & 566 & 533 \\
\hline 190 & 466 & 266 \\
\hline
\end{tabular}

* Paired studies are shown.

‡ Distance from subjects' teeth to the collecting orifice. they chose some starch-containing foods. Subsequent subjects received one of the three meals. Most of the carbohydrate fraction of each meal represented starch.

Table IV shows the glucose concentration of intestinal fluid after these meals. Except for the aspirations from the lowest intestinal level (162 $\mathrm{cm}$ from teeth), glucose concentrations were nearly always above 6.0 mmoles/liter, a concentration at which downhill transport from lumen to blood would occur. These concentrations were also higher than those which required sodium for optimal absorption in the perfusion studies.

TABLE III

Estimated Composition of Meals*

\begin{tabular}{|c|c|c|c|c|c|}
\hline Meal & $\begin{array}{l}\text { Major source of } \\
\text { carbohydrate }\end{array}$ & Calories & Protein & Fat & Carbohydrate \\
\hline & & & $g$ & $g$ & $g$ \\
\hline I & French toast & 619 & 7 & 25 & 112 \\
\hline II & Cheeseburger, pie & 1013 & 38 & 54 & 95 \\
\hline III & Potatoes, pie, eclair & 1459 & 60 & 48 & 178 \\
\hline
\end{tabular}

*In Agriculture Handbook No. 8. 1950. Composition of foods-raw processed, prepared. B. K. Wall and A. Merris, Washington, D. C. 

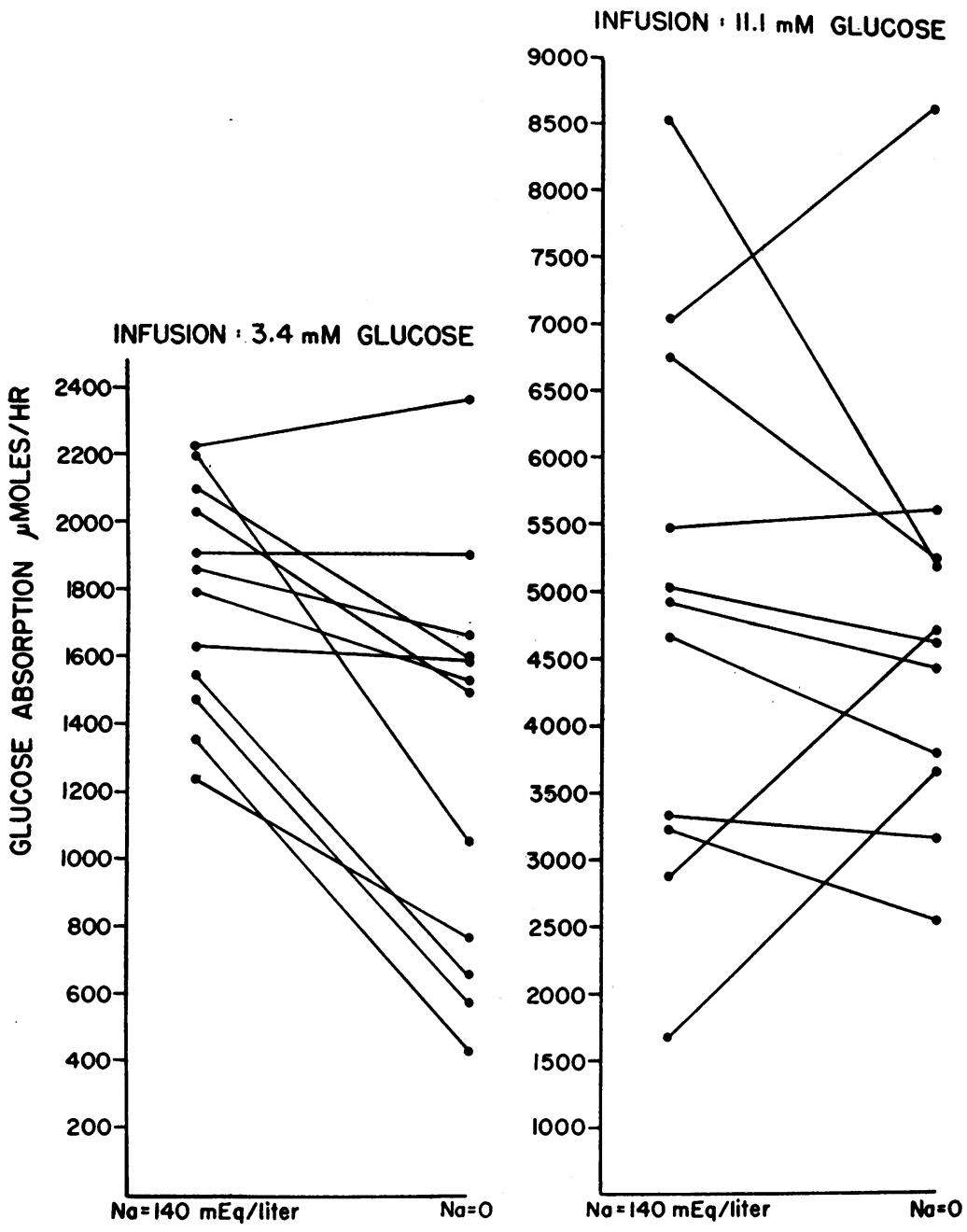

FIGURE 4 The relation of glucose absorption to sodium in the infusion with Tris- $\mathrm{HCl}$ as the asmotic replacement in sodium-free infusions. Significant inhibition of absorption occurred in the absence of sodium in the $3.4 \mathrm{mmoles} / \mathrm{liter}$ infusions $(P<0.005)$, but not in the $11.1 \mathrm{mmoles} /$ liter infusions.

\section{DISCUSSION}

The finding of inhibition of active glucose transport in man upon reducing intraluminal sodium concentration is consistent with the results of previous studies using intact animals. Csaky, for example, found an inhibition of $42 \%$ in rats when he replaced sodium with mannitol (17). In vitro studies, however, have shown a complete abolition of active sugar transport with replacement of sodium in the fluid bathing the mucosal side of the membrane. The findings in vivo, including our own, of only partial inhibition on removing sodium from the infusion have two possible explanations.
The first is that luminal sodium may not be as important in active transport of glucose in intact animals as it is in active transport in tissue preparations. The second is that, in contrast to in vitro studies where good control of sodium concentration may be possible, an in vivo technique such as ours makes use of relatively large areas of intestine that permit diffusion of sodium into the lumen. Thus the sodium concentration of the mucosal solution cannot be maintained at near zero levels, as is shown by our finding of a measurable concentration of sodium in all of our collection fluids.

In addition to inhibiting active absorption, 
TABLE IV

Glucose Concentrations in Small Intestine after Meals

\begin{tabular}{|c|c|c|c|c|c|c|c|c|c|c|c|c|c|}
\hline \multirow[b]{2}{*}{ Meal $\ddagger$} & \multirow[b]{2}{*}{ Levelई } & \multicolumn{12}{|c|}{ Collection period* } \\
\hline & & $0-10^{\prime}$ & $11-20^{\prime}$ & $21-30^{\prime}$ & $31-40^{\prime}$ & $41-50^{\prime}$ & $51-60^{\prime}$ & $61-70^{\prime}$ & $71-80^{\prime}$ & $81-90^{\prime}$ & $91-100^{\prime}$ & $101-110^{\prime}$ & $111-120^{\prime}$ \\
\hline \multirow{4}{*}{ I } & \multicolumn{13}{|c|}{ mmoles/liter } \\
\hline & 90 & 30.6 & 31.2 & 21.1 & 26.6 & 25.0 & 16.3 & 25.2 & 20.1 & 17.6 & 21.9 & 17.9 & 18.0 \\
\hline & 111 & $\|$ & 12.9 & 17.0 & 7.3 & 14.0 & 5.9 & 11.5 & 16.0 & 6.0 & 9.0 & 5.8 & 10.6 \\
\hline & 162 & 0.2 & 1.5 & 0.4 & 0.5 & 0.5 & 0.4 & 0.3 & 0.4 & 0.3 & 0.2 & 0.2 & 0.3 \\
\hline \multirow[t]{3}{*}{ II } & 100 & I & 12.9 & 23.3 & 18.7 & 9.9 & 31.9 & 22.2 & 1.9 & $\|$ & $\|$ & $\|$ & $\|$ \\
\hline & 129 & 47.7 & 42.0 & 6.1 & 0.2 & 0.3 & 4.5 & 3.4 & 1.7 & 3.4 & 3.1 & 2.3 & $\|$ \\
\hline & 135 & 9.0 & 9.3 & 5.0 & 11.3 & $\|$ & $\|$ & $\|$ & $\|$ & $\|$ & $\|$ & $\|$ & $\|$ \\
\hline \multirow[t]{2}{*}{ III } & 129 & 40.2 & 43.3 & 31.8 & 36.8 & 37.7 & 33.1 & 27.8 & 34.1 & 31.0 & $\|$ & $\|$ & $\|$ \\
\hline & 145 & 14.9 & 16.1 & 13.7 & 8.8 & 14.3 & 15.2 & $\|$ & $\|$ & $\|$ & $\|$ & $\|$ & $\|$ \\
\hline
\end{tabular}

* Time of collection period in minutes after meal finished.

$\ddagger$ See Table III for composition of meals.

$\S$ Distance from subjects' teeth to the collecting orifice.

\| No collections attempted during these periods.

II No collection could be obtained during these periods.

sodium-free perfusions resulted in fluid entering the intestinal test segment, probably because the effective osmotic pressure of solutions containing mannitol is higher than that of plasma, despite their identical osmolality (33). Despite the dilution occurring in the test segment during sodiumfree perfusion, the glucose concentration at the end of the segment was higher than when sodium was present. This finding indicates that the inhibition of glucose absorption during mannitol perfusion was not simply due to a lower mean intraluminal glucose concentration because of dilution.

Two findings suggest that solvent drag played little or no role in enhanced active absorption in the presence of sodium. First, the effect was only noted during uphill transport. With solvent drag one would expect an effect of sodium at all glucose concentrations; in fact a progressive increase in sample PEG concentration occurred with increasing infusion glucose concentrations in the presence of sodium, but not in the sodium-free studies, suggesting greater water absorption at the higher concentrations. Therefore one might expect to see an even greater enhancement by sodium at higher glucose concentrations if solvent drag were the crucial factor. Second, the deliberate enhancement of water absorption by reduction of the tonicity of the infusion solution so that water absorption exceeded that which occurred in the sodium infusions (Table II) did not increase glucose absorption.
The inhibition of active glucose transport did not appear to be the direct result of the substance used to replace sodium. First, the effect occurred with two different osmotic replacements, mannitol and Tris- $\mathrm{HCl}$. Second, prolonged studies of glucose absorption during mannitol infusion resulted in no falloff of absorption. Studies by others using in vitro systems have also suggested that the substances we used to replace sodium were not toxic in themselves $(17,9)$.

The lack of inhibition of glucose absorption by sodium-free solution at glucose concentrations higher than those of serum is consistent with the findings of Csaky (17) who, however, used a considerably higher glucose concentration (150 mmoles/liter) to study downhill transport in rats. Because of his findings he concluded that sodium was necessary only for energy-requiring active transport and was not involved in carrier-mediated entrance into the cell. Crane (16), however, has suggested that the major role of sodium is at the entrance step in forming a ternary complex with glucose and an equilibrating carrier. He postulated that the driving force for entrance of glucose and its accumulation is the downhill luminal-intracellular sodium gradient, with intracellular sodium concentration kept low by an energy-requiring sodium pump. Crane has attributed Csaky's finding of no sodium requirement at high glucose concentration to an additional effect of sodium, namely 


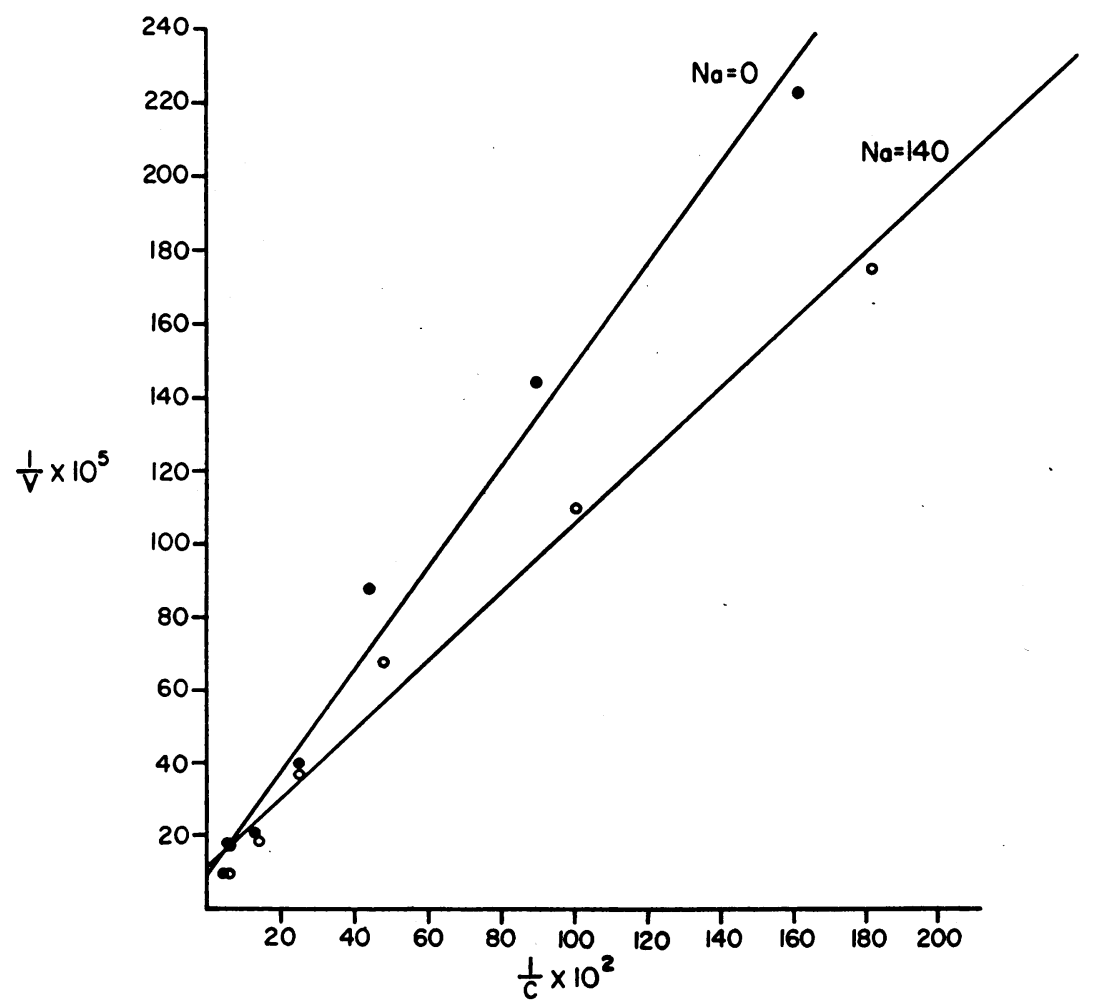

FIgURE 5 Lineweaver-Burk plot for glucose absorption. Values are calculated for the entire small intestine. $\mathrm{C}$ is geometric mean glucose concentration in mmoles/liter and $\mathrm{V}$ is glucose absorption in $\mu$ moles $/ \mathrm{hr}$.

that the affinity of the carrier for glucose is increased. In support of this proposal he has demonstrated in vitro a dependence of the apparent Michaelis constant of sugar transport on the sodium concentration of the incubation fluid; $V_{\max }$ was independent of the sodium concentration (34). Consequently, he felt that at very high sugar concentrations sodium would not be expected to have an effect.

Fig. 5 shows a Lineweaver-Burk plot of our data; we used geometric mean concentrations rather than infusion concentrations in order to approximate effective luminal concentrations; the decline in luminal glucose concentration appeared to more closely resemble a logarithmic function than a linear function of the length of the test segment. ${ }^{7}$ Others have also used this mean for similar calculation of kinetic data $(35,36)$. The curve is strikingly similar to those obtained by Crane, Forstner, and Eichholz (34). When ex-

7 Olsen, W., and F. J. Ingelfinger. Unpublished observations. pressed in this fashion, sodium appears to have had an effect at every concentration except when maximal transport rate was approached. It is, in fact, possible that at the higher glucose concentrations a very limited sodium requirement existed but that it was adequately met during sodium-free perfusion since some sodium was always found in intraluminal fluid, as shown in Fig. 1. These data indicate that the glucose transport system's sodium requirement for optimal absorption is a function of glucose concentration. Although the data appear most consistent with an effect of sodium on the carrier's affinity for glucose, they do not completely exclude the possibility of two transport mechanisms, one operating at low glucose concentration, requiring intraluminal sodium, and the other operating for downhill transport with no sodium requirement. Table $\mathrm{V}$ shows the kinetic constants derived from these plots. When separate plots for jejunum and ileum were made (ileal studies being those where the collecting point was $170 \mathrm{~cm}$ or more from the teeth), the effect of so- 
TABLE V

Kinetic Data*

\begin{tabular}{|c|c|c|}
\hline $\begin{array}{l}\text { Infusion sodium } \\
\text { concentration }\end{array}$ & $V_{\max }$ & $K_{m}$ \\
\hline$m E q /$ liter & $\begin{array}{l}\text { mmoles } / \mathrm{hr} \text { per } \\
10 \mathrm{~cm} \text { segment }\end{array}$ & mmoles/liter \\
\hline 0 & 10.6 & 15.4 \\
\hline 143 & 8.8 & 8.6 \\
\hline
\end{tabular}

* Derived from Fig. 5.

dium was similar: it decreased the $K_{m}$ from 46.7 to $31 \mathrm{mmoles} /$ liter in jejunum and from 15.3 to $10.0 \mathrm{mmoles} /$ liter in ileum without affecting $V_{\max }$, which was $29 \mathrm{mmoles} / \mathrm{hr}$ in jejunum and 8 mmoles/hr in ileum. These constants are different from those calculated by others in man (37-39) ; however, these authors constructed their kinetic plots on the basis of infusion concentrations, and they used longer intestinal segments in which the effective concentration over the entire segment might be expected to be considerably lower than the infusion concentration. Thus their higher values are not surprising. Our data are more consistent with those of Fisher and Parsons who studied rat intestine in an in vitro system and obtained a $K_{m}$ of about 8 mmoles/liter (40).

Our findings may partially explain the inability of Fleshler, Butt, and Wismar to show an inhibition of glycine absorption in man with sodiumfree perfusions (35). They used a glycine concentration of 75 mmoles/liter, a level which was about equal to their calculated Michaelis constant, and at which an effect of sodium might not be noticed. Another possibility is that because these workers used a longer test segment and a slower infusion rate, greater equilibration of luminal fluid with intracellular sodium could occur.

The finding that glucose concentrations in the upper small intestine after a carbohydrate meal usually exceeded that of serum, even up to $2 \mathrm{hr}$ after the meal, is consistent with the observation of Dahlqvist and Borgström who found total carbohydrate concentrations of between 3000 to 6500 $\mathrm{mg} / 100 \mathrm{ml}$ of which $5-10 \%$ was free glucose (41). Our observations suggest that a large, if not the major part, of glucose absorption in man occurs in a downhill direction at concentrations where there is only a very limited, if any, dependence upon intraluminal sodium concentration.

\section{ACKNOWLEDGMENTS}

The authors are grateful to Miss Elizabeth Hovey and Mrs. Vernice Smith for technical assistance.

This work was supported in part by U. S. Public Health Service Research grant AM-03560 and Training grant TI AM-5025 from the National Institute of Arthritis and Metabolic Diseases, National Institutes of Health, Bethesda, Md.

\section{REFERENCES}

1. Schultz, S. G., and R. Zalusky. 1963. The interaction between active sodium transport and active sugar transport in the isolated rabbit ileum. Biochim. Biophys. Acta. 71: 503.

2. Schultz, S. G., and R. Zalusky. 1964. Ion transport in isolated rabbit ileum. II. The interaction between active sodium and active sugar transport. J. Gen. Physiol. 47: 1943.

3. Levinson, R. A., and H. P. Schedl. 1966. Absorption of sodium, chloride, water, and simple sugars in rat small intestine. Am. J. Physiol. 211: 939.

4. Schedl, H. P., and J. A. Clifton. 1963. Solute and water absorption by the human small intestine. Nature. 199: 1264.

5. Malawer, S. J., M. Ewton, J. S. Fordtran, and F. J. Ingelfinger. 1965. Interrelation between jejunal absorption of sodium, glucose and water in man. $J$. Clin. Invest. 44: 1072. (Abstr.)

6. Taylor, J., N. Hirschhorn, and R. A. Phillips. 1967. Enhancement by intestinal glucose lavage of net sodium and water absorption in acute cholera patients. Federation Proc. 26: 384. (Abstr.)

7. Riklis, E., and J. H. Quastel. 1958. Effects of cations on sugar absorption by isolated surviving guinea pig intestine. Can. J. Biochem. Physiol. 36: 347.

8. Csáky, T. Z., and M. Thale. 1960. Effect of ionic environment on intestinal sugar transport. J. Physiol. (London). 151: 59.

9. Bihler, I., and R. K. Crane. 1962. Studies on the mechanism of intestinal absorption of sugars. V. The influence of several cations and anions on the active transport of sugars, in vitro, by various preparations of hamster small intestine. Biochim. Biophys. Acta. 59: 78.

10. Schultz, S. G., R. E. Fuisz, and P. F. Curran. 1966. Amino acid and sugar transport in rabbit ileum. J. Gen. Physiol. 49: 849.

11. Csáky, T. Z., and L. Zollicoffer. 1960. Ionic effect on intestinal transport of glucose in the rat. Am. J. Physiol. 198: 1056.

12. Annegers, J. H. 1964. Some effects of cations and of water absorption on intestinal hexose, glycine and cation absorption. Proc. Soc. Exptl. Biol. Med. 116: 933.

13. Csáky, T. Z. 1961. Significance of sodium ions in active intestinal transport of nonelectrolytes. Am. J. Physiol. 201: 999.

14. Rosenberg, I. H., A. L. Coleman, and L. E. Rosenberg. 1965. The role of sodium ion in the transport 
of amino acids by the intestine. Biochim. Biophys. Acta. 102 : 161.

15. Playoust, M. R., and K. J. Isselbacher. 1964. Studies on the transport and metabolism of conjugated bile salts by intestinal mucosa. J. Clin. Invest. $43: 467$.

16. Crane, R. K. 1965. $\mathrm{Na}^{+}$-dependent transport in the intestine and other animal tissues. Federation Proc. 24: 1000 .

17. Csáky, T. Z. 1963. A possible link between active transport of electrolytes and nonelectrolytes. Federation Proc. 22: 3 .

18. Fordtran, J. S., K. H. Soergel, and F. J. Ingelfinger. 1962. Intestinal absorption of $\mathbf{D}$-xylose in man. New Engl. J. Med. 267: 274.

19. Shaffer, C. B., and F. H. Critchfield. 1947. The absorption and excretion of the solid polyethylene glycols ("carbowax" compounds). J. Am. Pharm. Assoc. 36: 152.

20. Hyden, S. 1956. The recovery of polyethylene glycol after passage through the digestive tract. Kungl. Lantbrukshögskolans Annaler. 22: 411.

21. Jacobson, E. D., D. C. Bondy, S. A. Broitman, and J. S. Fordtran. 1963. Validity of polyethylene glycol in estimating intestinal water volume. Gastroenterology. 44: 761.

22. Goulston, K., W. Olsen, and L. Harris. 1966. Evaluation of assumptions necessary in marker-perfusion studies. Clin. Res. 14: 297. (Abstr.)

23. Somogyi, M. 1945. Determination of blood sugar. $J$. Biol. Chem. 160: 69.

24. Hyden, S. 1956. A turbidimetric method for the determination of higher polyethylene glycols in biological materials. Kungl. Lantbrukshögskolans Annaler. 22 : 139.

25. Gray, G. M., and F. J. Ingelfinger. 1965. Intestinal absorption of sucrose in man. The site of hydrolysis and absorption. J. Clin Invest. 44: 390.

26. Huggett, A. St. G., and D. A. Nixon. 1957. Use of glucose oxidase, peroxidase, and $o$-dianisidine in determination of blood and urinary glucose. Lancet. 2: 368.

27. Talley, R. B., H. P. Schedl, and J. A. Clifton. 1964. Small intestinal glucose, electrolyte and water absorption in cirrhosis. Gastroenterology. $47: 382$.

28. Cooper, H., R. Levitan, J. S. Fordtran, and F. J. Ingelfinger. 1966. A method for studying absorption of water and solute from the human small intestine. Gastroenterology. 50: 1 .

29. Whalen, G., J. Harris, and K. Soergel. 1965. Bidirectional flux of sodium and water in the human small intestine. Gastroenterology. 48: 859. (Abstr.)

30. Phillips, S. F., and W. H. J. Summerskill. 1966. Occlusion of the jejunum for intestinal perfusion in man. Mayo Clinic Proc. 41: 224.

31. Csáky, T. Z., and P. M. Ho. 1966. The effect of potassium on the intestinal transport of glucose. J. Gen. Physiol. 50: 113. Fordtran, J. S. 1967. Summary and comment. Gastroenterology. 52: 738.

32. Meyer, K. H., and W. F. Gonon. 1951. La dégradation de l'amylose par les $\alpha$-amylases. Recherches sur l'Amidon 50. Helv. Chim. Acta. 34: 294.

33. Fordtran, J. S. 1967. Speculations on the pathogenesis of diarrhea. Federation Proc. 26: 1405.

34. Crane, R. K., G. Forstner, and A. Eichholz. 1965. Studies on the mechanism of the intestinal absorption of sugars. X. An effect of $\mathrm{Na}^{+}$concentration on the apparent Michaelis constants for intestinal sugar transport, in vitro. Biochim. Biophys. Acta. 109: 467.

35. Fleshler, B., J. H. Butt, and J. D. Wismar. 1966. Absorption of glycine and L-alanine by the human jejunum. J. Clin. Invest. 45: 1433.

36. Rider, A. K., H. P. Schedl, G. Nokes, and S. Shining. 1967. Small intestinal glucose transport. Proximaldistal kinetic gradients. J. Gen. Physiol. 50: 1173.

37. Holdsworth, C. D., and A. M. Dawson. 1964. The absorption of monosaccharides in man. Clin. Sci. 27: 371.

38. Gray, G. M., and F. J. Ingelfinger. 1966. Intestinal absorption of sucrose in man: interrelation of hydrolysis and monosaccharide product absorption. $J$. Clin. Invest. 45: 388.

39. Schedl, H. P., and J. A. Clifton. 1963. Kinetics of intestinal absorption in man: normals and patients with sprue. In 2nd World Congress of Gastroenterology. Munich, 1962. S. Karger, New York. 2: 728.

40. Fisher, R. B., and D. S. Parsons. 1953. Glucose movements across the wall of the rat small intestine. $J$. Physiol. (London). 119: 210.

41. Dahlqvist, A., and B. Borgström. 1961. Digestion and absorption of disaccharides in man. Biochem. J. 81: 411. 